\title{
Effects of extruded flaxseed and dietary rumen undegradable protein on reproductive traits and the blood metabolites in Baluchi ewes
}

\author{
R. Ababakri', O. Dayani ${ }^{1,3}$, A. Khezri ${ }^{1}$ and A.A. Naserian ${ }^{2}$ \\ ${ }^{1}$ Shahid Bahonar University of Kerman, Faculty of Agriculture, Kerman 7616013439, Iran \\ ${ }^{2}$ Ferdowsi University of Mashhad, Faculty of Agriculture, Department of Animal Science, Mashhad 9177948974, Iran
}

KEY WORDS: by-pass protein, ewes, fertility, flax, hormones

Received: 18 March 2021

Revised: 26 May 2021

Accepted: 17 June 2021
${ }^{3}$ Corresponding author:

e-mail: odayani@uk.ac.ir
ABSTRACT. This study was carried out to compare the effects of flushing diets with different levels of extruded flaxseed (EFS) and rumen undegradable protein (RUP) on reproductive performance and blood metabolites in Baluchi ewes. Forty-eight ewes (2-3 years old) were fed one of four different treatment diets: 1) no EFS + 20\% RUP, 2) no EFS + 40\% RUP, 3) $10 \%$ EFS + 20\% RUP and 4) $10 \%$ EFS $+40 \%$ RUP. Blood concentrations of glucose ( $24 \mathrm{~h}$ after removing controlled internal drug release (CIDR) containing $0.3 \mathrm{~g}$ of progesterone) and cholesterol ( $24 \mathrm{~h}$ before removing CIDR) were different among the dietary treatments $(P<0.05)$. Blood urea-N $(24 \mathrm{~h}$ after removing CIDR and 9 days after mating) was also impacted by the dietary treatments $(P<0.05)$. Higher blood estrogen levels occurred in response to EFS supplementation plus $40 \%$ RUP in comparison to non-EFS diets both $24 \mathrm{~h}$ before and after removing CIDR. Blood progesterone in ewes fed 10\% EFS and 40\% RUP diet was increased 9 days after mating in comparison to ewes fed non-EFS diets $(P<0.05) .10 \%$ EFS and $40 \%$ RUP in the diets of ewes improved the fecundity rate $(P<0.05)$. Follicle and corpus diameter ( $24 \mathrm{~h}$ after CIDR removal and 9 days after mating, respectively) were higher in EFS diets than the other groups $(P<0.05)$. So, the use of $10 \%$ EFS as a source of omega-3 fatty acids with $40 \%$ RUP in the flushing diet can improve ewe reproduction performance, which is important in the sheep industry, especially in developing countries.

\section{Introduction}

The profitability of the sheep industry depends chiefly on conception and fecundity rates and can be increased by nutritional flushing of the ewes before mating. Flushing diets act via the hypothalamuspituitary-gonadal axis affecting the secretion of hormone including insulin, progesterone and estrogen (Scaramuzzi et al., 2006). Flaxseed is a good source of plant unsaturated fatty acids (FA) like $\alpha$-linolenic acid (ALA; C18:3n-3, an omega-3 FA that constitutes $57 \%$ of the total fats in flax oil) and linoleic acid (LA: C18:2n-6, an omega-6 FA that constitutes $16 \%$ of the total fats in flax oil), and has been found to improve production and reproduction performance of animals in addition to enhancing the quality of animal products. Adding flaxseed to dairy cows' diet changed the FA composition of blood plasma, follicular fluid and reproductive tissues (Zachut et al., 2010) as well as improved the metabolic and physiological status of the uterus, oocyte and embryo (Marei et al., 2009; Zachut et al., 2010). Wonnacott et al. (2010) reported that diets contrasting in n-3 and n- 6 polyunsaturated fatty acids (PUFAs) were effective in altering the FA composition of both granulosa cells and oocytes and led to 
differences in progesterone concentrations in ovarian follicular fluid.

Intake of rumen degradable protein (RDP) in excess of microbial utilization subjected to pre duodenal $\mathrm{N}$ losses, increases animal energy requirements and reduces embryo survival in sheep. In addition, the excretion of urea $\mathrm{N}$ contributes to environmental pollutants such as atmospheric ammonia $\left(\mathrm{NH}_{3}\right)$ and nitrates in groundwater (Mikolayunas et al., 2011). Also, elevated dietary protein has been associated with depressed reproductive efficiency in dairy cattle. Excess crude protein (CP) is degraded to $\mathrm{NH}_{3}$ by ruminal microbes, absorbed into the portal blood and rapidly converted into urea by the liver. High concentrations of plasma urea nitrogen (PUN) have been associated with lowered pregnancy rates in dairy cows. Supplementing diets with rumen undegradable protein (RUP) sources has been shown to lower PUN and improve reproductive indices (McCormick et al., 1999). Furthermore, Berardinelli et al. (2001) reported that the effects of excess degradable intake protein on embryonic survival in sheep may occur early (from day 4 to 11 ) during embryonic development. However, these effects may occur sooner, during the initial stages of development in the oviduct. The effects on the early developing embryo may be carried over into later stages of development or cause a change in the ability of the embryo to synchronize its development with uterine changes necessary to sustain it.

Baluchi ewes are usually kept in different regions including drought and semi-drought areas of southwest Pakistan, eastern Iran and southern Afghanistan with a notable influence on rural livelihood. Baluchi sheep is a seasonal breed that usually delivers one lamb during mating season but its reproductive function might be enhanced by nutritional flushing prior to breeding. Supplementing the flushing diets with some energy (e.g., unsaturated FA, n-3) or protein sources has been already shown to improve fertility parameters but in dairy cows (Staples and Thatcher, 2005; Cerri et al., 2009; Aboozar et al., 2012). However, to authors' knowledge, no reports are available considering the combined effects of n-3 PUFAs and protein source on sheep reproductive function. So, we hypothesized that the combined effects of feeding extruded flaxseed and different levels of RUP would be more effective in enhancing ewes fertility than feeding high RUP alone. Hence, this study investigated the alterations in reproductive characteristics and blood metabolites in Baluchi ewes in response to feeding different levels of extruded flaxseed ( 0 and $10 \%)$ and RUP (20 and 40\%) during the flushing stage.

\section{Material and methods}

\section{Animals, diets and experimental design}

Forty-eight multiparous Baluchi ewes (48.7 \pm $2.8 \mathrm{~kg}$ of body weight (BW), $3.2 \pm 0.2$ of body condition score (BCS) and 2-3 years old at the beginning of the experiment) were randomly allocated to four groups (12 ewes in each group) in a $2 \times 2$ factorial arrangement in a completely randomized design. The study was conducted from August to September 2018 at the Torbat-e-Jam sheep breeding centre (Iran) (latitude: $35^{\circ} 14^{\prime} 38.40^{\prime \prime} \mathrm{N}$ and longitude: $\left.60^{\circ} 37^{\prime} 21.00^{\prime \prime} \mathrm{E}\right)$. To adapt animals to the housing conditions and standardize their dietary background, the ewes were placed in individual pens $(1 \times 1.76 \mathrm{~m})$ and fed a maintenance diet for two weeks prior to application of the treatments. From day 15, the ewes were fed twice daily (at 8:00 and 16:00) with equal meals of one of the four isonitrogenous and iso-caloric diets formulated according to the National Research Council (NRC, 2007) (Table 1). Water and feed were freely available to all experimental animals. The experiment procedures (including feeding the flushing diets, oestrous and

Table 1. The ingredients and chemical composition of diets fed to ewes during the flushing period

\begin{tabular}{lcccc}
\hline \multirow{2}{*}{ Indices } & \multicolumn{4}{l}{ Dietary treatments ${ }^{1}$} \\
\cline { 2 - 5 } & \multicolumn{1}{c}{ T2 } & \multicolumn{1}{c}{ T3 } & T4 \\
\hline Ingredients, \% DM & & & & \\
maize silage & 66.5 & 66.5 & 66.5 & 66.5 \\
wheat straw & 6.0 & 6.0 & 6.0 & 6.0 \\
barley grain & 14.0 & 14.0 & 4.0 & 4.0 \\
beet pulp & 6.0 & 3.0 & 6.0 & 3.0 \\
wheat bran & 6.0 & 3.0 & 6.0 & 3.0 \\
extruded flaxseed & 0.0 & 0.0 & 10.0 & 10.0 \\
urea & 1.0 & 0.0 & 1.0 & 0.0 \\
Yasminomax & 0.0 & 7.0 & 0.0 & 7.0 \\
calcium carbonate & 0.22 & 0.22 & 0.22 & 0.22 \\
minerals-vitamins ${ }^{3}$ & 0.14 & 0.14 & 0.14 & 0.14 \\
salt & 0.14 & 0.14 & 0.14 & 0.14 \\
Chemical composition, \% & & & & \\
metabolizable energy, Mcal/kg & 2.27 & 2.29 & 2.31 & 2.36 \\
crude protein & 12.3 & 12.1 & 12.3 & 12.2 \\
neutral detergent fibre & 49.7 & 48.9 & 49.6 & 49.1 \\
acid detergent fibre & 26.6 & 25.7 & 26.9 & 25.8 \\
ether extract & 3.0 & 3.1 & 5.5 & 5.5 \\
rumen undegradable protein & 20.4 & 39.8 & 20.3 & 39.7 \\
rumen degradable protein & 79.6 & 60.2 & 79.7 & 60.3 \\
calcium & 0.55 & 0.52 & 0.61 & 0.58 \\
phosphorus & 0.32 & 0.35 & 0.3 & 0.34 \\
\hline
\end{tabular}

${ }^{1}$ treatments: T1 - no extruded flaxseed (EFS) $+20 \%$ RUP (rumen undegradable protein), T2 - no EFS + 40\% RUP, T3 - 10\% EFS + $20 \%$ RUP, T4 - 10\% EFS + 40\% RUP; ${ }^{2}$ Yasminomax contained $46 \%$ CP, $70 \%$ RUP, $7 \%$ ash, $4 \%$ fat (DM basis); ${ }^{3}$ mineral and vitamin mix contained per kg: g: Ca 200, P 98, Mg 21, Na 44, Cu 0.3, Mn 2, Fe 3, Zn 3, I 0.1, Co 0.1, Se 0.001, IU: vitamin A 500 000, vitamin $D_{3}$ 100 000, mg: vitamin E 100, antioxidant 400; DM - dry matter 


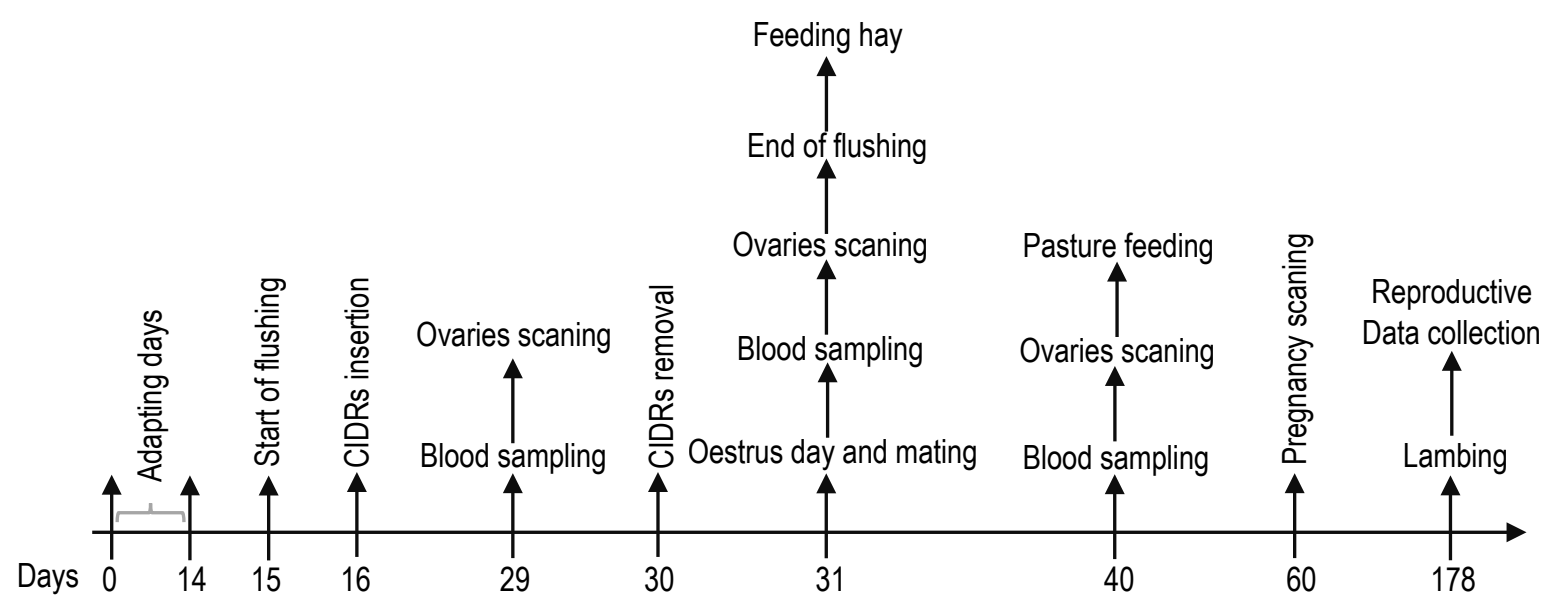

Figure 1. Schematic depiction of the experimental plan (including oestrous and mating synchronization, blood sampling, ovaries scanning and collection of reproductive data)

CIDR - controlled internal drug release

mating synchronization, blood sampling, ovaries scanning and collection of reproductive data) were carried out as indicated in Figure 1.

The experimental diets were: 1) no extruded flaxseed (EFS) diet $+20 \%$ RUP, 2) no EFS diet + $40 \%$ RUP, 3) $10 \%$ EFS + 20\% RUP, and 4) $10 \%$ EFS $+40 \%$ RUP. Flaxseed was extruded at $150{ }^{\circ} \mathrm{C}$ for $15 \mathrm{~s}$ and Yasminomax (46\% CP and 70\% RUP) (Sanadam Pars Company, Tehran, Iran) was used as the source of RUP. The chemical composition and FA profile of flaxseed used in flushing diets are shown in Table 2.

Table 2. The chemical composition and fatty acids profile of flaxseed used in the flushing diets

\begin{tabular}{lc}
\hline Indices & Content \\
\hline Chemical composition, \% dry matter (DM) & \\
DM, \% fresh weight & 94.62 \\
crude protein & 18.70 \\
ether extract & 41.05 \\
neutral detergent fibre & 22.21 \\
acid detergent fibre & 18.73 \\
ash & 2.95 \\
Fatty acids profile (g/100 g of total fatty acids) & \\
C12:0 & \\
C14:0 & \\
C16:0 & 0.038 \\
C16:1 & 5.02 \\
C17:0 & 0.048 \\
C17:1 & 0.06 \\
C18:0 & 0.04 \\
C18:1-cis9 & 4.27 \\
C18:2-cis9,12 & 20.02 \\
C18:3-cis9,12,15 & 17.11 \\
C20:0 & 52.83 \\
C20:1 & 0.13 \\
C22:0 & 0.12 \\
C24:0 & 0.09 \\
\hline
\end{tabular}

Oestrous cycles were synchronized by insertion of vaginal insert (CIDR; EAZL-BREED CIDR Sheep Insert, Pfizer New Zealand Ltd, Auckland, New Zealand) constructed with a silicone elastomer impregnated with $0.3 \mathrm{~g}$ natural progesterone (P4) from day 16 to day 30 of the experimental period. Fertile and healthy rams (three per treatment) were introduced $24 \mathrm{~h}$ after CIDR removal (oestrous day) (Figure 1). No gonadotropin was injected after removal of the CIDR in order to evaluate the influence of dietary treatments on follicle and corpus luteum conditions.

All procedures of animal handling were approved by the Animal Care and Use Committee of Shahid Bahonar University of Kerman (Iran) in accordance with EU standards (Directive 2010/63).

\section{Measurements and analytical methods}

Over the period of flushing, individual dry matter intake (DMI) was measured daily, and the ewes were weighed weekly before the morning meal. Blood samples were obtained from the jugular vein $24 \mathrm{~h}$ prior to CIDR withdrawal, $24 \mathrm{~h}$ after CIDR withdrawal and 9 days after CIDR withdrawal. Blood samples were collected in non-heparinised Vacutainer tubes and placed into icy water immediately following the collection. Then the serum was obtained after centrifugation at $3000 \mathrm{~g}$ for $15 \mathrm{~min}$. The obtained serum was stored at $-20^{\circ} \mathrm{C}$ until subsequent analyses. Serum glucose (No. 017-5001, Pars Azmon Co., Karaj, Iran), cholesterol (No. 010-500-1, Pars Azmon Co., Karaj, Iran) and urea (No. 1-400-030, Pars Azmon Co., Karaj, Iran) concentrations were analysed by auto-analyzer (Abbott Alcyon 300, Abbott Laboratories, Inc. Irving, TX, USA). Serum concentrations of hormones including insulin (No. 2425-300, Monobind Inc, Lake Forest, CA, USA), estradiol (No. 4925-300, Monobind 
Inc., Lake Forest, CA, USA) and progesterone (No. 4825-300, Monobind Inc., Lake Forest, CA, USA) were analyzed with the use of ELISA reader (Stat Fax 3200 Microplate Reader, Awareness Technology Inc., Palm City, FL, USA). All assays for analyses of blood parameters were done in accordance with the manufacturers' guidelines.

\section{Ultrasonography assessments}

The size and number of follicles at $24 \mathrm{~h}$ before and after CIDR withdrawal and size of corpus luteum 9 days after mating (Figure 1) were determined by a ultrasonography (Wed3100 ultrasound scanner with 7.5 MHz probe, Shenzhen, China). The reproductive data collected were: fecundity rate (number of lambs born / number of bred ewes in the group $\times 100$ ); twinning rate (number of ewes delivering twin / number of ewes delivering in the group $\times 100$ ); fertility rate (number of delivered ewes / number of bred ewes $\times 100$ ); male lamb rate (number of born male lamb / whole number of born lambs $\times 100$ ); and female lamb rate (number of female lambs born / number of lambs born $\times 100$ ).

\section{Statistical analyses}

This experiment was carried out in a $2 \times 2$ factorial arrangement in a completely randomized design. Data on DMI, BW, blood hormone levels, metabolite concentrations, the number and the size of follicles, and the size of corpora lutea were statistically analysed by the PROC MIXED of SAS (2003, SAS Institute Inc., Cary, NC, USA). The model used was:

$$
\mathrm{Y}_{i j k}=\mu+\mathrm{A}_{i}+\mathrm{B}_{j}+(\mathrm{AB})_{i j}+\mathrm{C}_{k}+\varepsilon_{i j k},
$$

where: $\mathrm{Y}_{i j k}$ - dependent variable, $\mu$ - overall mean, $\mathrm{A}_{i}$ - fixed effect of flaxseed, $\mathrm{B}_{j}-$ fixed effect of RUP, $(\mathrm{AB})_{i j}$ - flaxseed and RUP interaction,
$\mathrm{C}_{k}$ - random effect of animal $k$ and $\varepsilon_{i j k}$ - residual error. Categorical variables or variables expressed as percentages, including fecundity rate, fertility rate, twinning rate, female lamb rate and male lamb rate, were analysed by the Chi-square test. The test of Tukey $(P<0.05)$ was used to compare the mean values of dietary treatments. Unless otherwise stated, the differences were considered statistically significant at $P<0.05$. A tendency was declared when the $P$-value was in the range of $0.05<P<0.10$.

\section{Results}

\section{Dry matter and nutrients intake, body weight}

The DMI and BW of the ewes were not affected by the use of different levels of EFS and RUP during the stage of flushing (Table 3). The intake of all nutrients was affected by experimental diets as well as by the use of $10 \%$ EFS, as the intakes of metabolizable energy (ME), CP, NDF (neutral detergent fibre), ether extract (EE) and RUP were greater (Table $3, P<0.01$ ) for ewes fed diets with $10 \%$ EFS than for ewes fed diets with no flaxseed addition. Also, the intakes of ME and RUP were greater $(P<0.05)$ for ewes fed diets with $40 \%$ RUP than for ewes fed diets with 20\% RUP, and the intake of RDP was greater $(P<0.01)$ for ewes fed diets with $20 \%$ RUP than for ewes fed diets with $40 \%$ RUP.

\section{Blood metabolites and hormones}

Blood glucose concentration in the ewes fed $10 \%$ EFS and 40\% RUP diet, was higher $24 \mathrm{~h}$ after CIDR withdrawal in comparison to the group fed with no flaxseed (Table $4, P<0.05$ ). Blood cholesterol concentrations increased with the addition of extruded flaxseed before CIDR

Table 3. Effects of extruded flaxseed (EFS) and rumen undegradable protein (RUP) levels in the flushing diets on dry matter intake (DMI), body weight $(\mathrm{BW})$ and the intake of nutrients of the ewes

\begin{tabular}{|c|c|c|c|c|c|c|c|c|}
\hline \multirow{2}{*}{ Indices } & \multicolumn{4}{|c|}{ Dietary treatment ${ }^{1}$} & \multirow{2}{*}{ SEM } & \multicolumn{3}{|l|}{$P$-value } \\
\hline & $\overline{\mathrm{T} 1}$ & T2 & T3 & T4 & & EFS & RUP & EFS^RUP \\
\hline DMl, kg/day & 1.12 & 1.14 & 1.18 & 1.17 & 0.02 & 0.35 & 0.08 & 0.24 \\
\hline BW, kg & 50.04 & 50.51 & 50.83 & 50.96 & 1.12 & 0.54 & 0.87 & 0.83 \\
\hline \multicolumn{9}{|c|}{ Intake of nutrients } \\
\hline ME, Mcal & $2.50^{\mathrm{b}}$ & $2.57^{\mathrm{b}}$ & $2.68^{a}$ & $2.74^{\mathrm{a}}$ & 0.019 & $<0.0001$ & 0.012 & 0.79 \\
\hline $\mathrm{CP}, \mathrm{g}$ & $136^{b}$ & $136^{b}$ & $142^{\mathrm{a}}$ & $142^{\mathrm{a}}$ & 0.001 & 0.0007 & 0.89 & 0.68 \\
\hline$N D F, g$ & $549^{b}$ & $549^{b}$ & $575^{a}$ & $570^{a}$ & 0.004 & 0.0005 & 0.59 & 0.49 \\
\hline$A D F, g$ & $294^{\text {bc }}$ & $289^{\circ}$ & $312^{a}$ & $299^{b}$ & 0.002 & 0.0002 & 0.005 & 0.14 \\
\hline $\mathrm{EE}, \mathrm{g}$ & $33^{b}$ & $35^{b}$ & $64^{\mathrm{a}}$ & $64^{\mathrm{a}}$ & 0.0004 & $<0.0001$ & 0.17 & 0.17 \\
\hline RUP, g & $28^{c}$ & $54^{b}$ & $29^{c}$ & $56^{\mathrm{a}}$ & 0.0004 & 0.0012 & $<0.0001$ & 0.22 \\
\hline RDP, $g$ & $108^{b}$ & $82^{c}$ & $114^{a}$ & $85^{c}$ & 0.0007 & 0.0003 & $<0.0001$ & 0.16 \\
\hline
\end{tabular}

${ }^{1}$ treatments: T1 - no EFS + 20\% RUP, T2 - no EFS + 40\% RUP, T3 - 10\% EFS + 20\% RUP, T4 - 10\% EFS + 40\% RUP; SEM - standard error of the mean, ME - metabolizable energy, $\mathrm{CP}$ - crude protein, NDF - neutral detergent fibre, ADF - acid detergent fibre, EE - ether extract, RDP - rumen degradable protein; ${ }^{a-c}-$ means within the same row with different superscripts are significantly different at $P<0.05$ 
Table 4. Effects of extruded flaxseed (EFS) and rumen undegradable protein (RUP) levels in the flushing diets on blood metabolites concentrations of the ewes, $\mathrm{mg} / \mathrm{dl}$

\begin{tabular}{|c|c|c|c|c|c|c|c|c|}
\hline \multirow{2}{*}{ Indices } & \multicolumn{4}{|c|}{ Dietary treatment $^{1}$} & \multirow{2}{*}{ SEM } & \multicolumn{3}{|c|}{$P$-value } \\
\hline & $\mathrm{T1}$ & $\mathrm{T} 2$ & T3 & T4 & & EFS & RUP & EFS^RUP \\
\hline \multicolumn{9}{|c|}{$24 \mathrm{~h}$ before CIDR removal } \\
\hline glucose & 69.30 & 68.20 & 74.20 & 75.60 & 3.68 & 0.07 & 0.37 & 0.89 \\
\hline cholesterol & $64.27^{b}$ & $63.34^{\mathrm{b}}$ & $72.31^{\mathrm{a}}$ & $74.40^{\mathrm{a}}$ & 3.72 & 0.01 & 0.26 & 0.04 \\
\hline urea-N & 15.03 & 14.11 & 14.24 & 13.09 & 1.29 & 0.32 & 0.24 & 0.31 \\
\hline \multicolumn{9}{|c|}{$24 \mathrm{~h}$ after CIDR removal } \\
\hline glucose & $72.80^{c}$ & $74.60^{\text {bc }}$ & $76.50^{\mathrm{ab}}$ & $79.80^{\mathrm{a}}$ & 1.81 & 0.04 & 0.06 & 0.03 \\
\hline cholesterol & 67.35 & 68.22 & 74.18 & 75.47 & 3.91 & 0.17 & 0.92 & 0.39 \\
\hline urea-N & $15.47^{a}$ & $14.60^{\mathrm{a}}$ & $14.53^{\mathrm{a}}$ & $12.36^{b}$ & 0.83 & 0.04 & 0.05 & 0.08 \\
\hline \multicolumn{9}{|c|}{9 days after mating } \\
\hline glucose & 68.38 & 71.51 & 69.20 & 73.41 & 2.55 & 0.65 & 0.11 & 0.09 \\
\hline cholesterol & 59.40 & 57.14 & 60.69 & 66.80 & 3.39 & 0.08 & 0.07 & 0.12 \\
\hline urea-N & $20.92^{\mathrm{a}}$ & $17.95^{\mathrm{b}}$ & $18.26^{b}$ & $15.21^{\mathrm{c}}$ & 0.78 & 0.12 & 0.03 & 0.01 \\
\hline
\end{tabular}

${ }^{1}$ treatments: T1 - no EFS + 20\% RUP, T2 - no EFS + 40\% RUP, T3 - 10\% EFS + 20\% RUP, T4 - 10\% EFS + 40\% RUP; SEM - standard error of the mean, CIDR - controlled internal drug release; ${ }^{a-c}$ - means within the same row with different superscripts are significantly different at $P<0.05$

Table 5. Effects of extruded flaxseed (EFS) and rumen undegradable protein (RUP) levels in the flushing diets on blood hormones concentrations of the ewes

\begin{tabular}{|c|c|c|c|c|c|c|c|c|}
\hline \multirow{2}{*}{ Indices } & \multicolumn{4}{|c|}{ Dietary treatment ${ }^{1}$} & \multirow{2}{*}{ SEM } & \multicolumn{3}{|c|}{$P$-value } \\
\hline & $\mathrm{T1}$ & $\mathrm{T} 2$ & T3 & T4 & & EFS & RUP & EFS^RUP \\
\hline \multicolumn{9}{|l|}{$24 \mathrm{~h}$ before CIDR removal } \\
\hline insulin, IU/ml & 9.86 & 9.97 & 10.76 & 10.43 & 2.01 & 0.19 & 0.62 & 0.67 \\
\hline estradiol, pg/ml & $20.90^{b}$ & $21.61^{b}$ & $26.64^{\mathrm{ab}}$ & $27.83^{a}$ & 2.24 & 0.02 & 0.07 & $<0.001$ \\
\hline progesterone, $\mathrm{ng} / \mathrm{ml}$ & 2.43 & 2.56 & 2.76 & 2.84 & 0.61 & 0.84 & 0.37 & 0.65 \\
\hline \multicolumn{9}{|l|}{$24 \mathrm{~h}$ after CIDR removal } \\
\hline insulin, IU/ml & 9.96 & 10.08 & 12.56 & 13.12 & 2.17 & 0.89 & 0.64 & 0.78 \\
\hline estradiol, pg/ml & $30.51^{b}$ & $32.90^{b}$ & $56.31^{a}$ & $55.76^{a}$ & 2.13 & 0.01 & 0.09 & $<0.001$ \\
\hline progesterone, $\mathrm{ng} / \mathrm{ml}$ & 1.24 & 1.16 & 1.45 & 1.96 & 0.45 & 0.25 & 0.12 & 0.07 \\
\hline \multicolumn{9}{|l|}{9 days after mating } \\
\hline insulin, IU/ml & 10.31 & 10.58 & 12.89 & 13.67 & 1.73 & 0.97 & 0.09 & 0.08 \\
\hline estradiol, pg/ml & 20.24 & 20.35 & 21.27 & 21.49 & 2.45 & 0.39 & 0.45 & 0.21 \\
\hline progesterone, $\mathrm{ng} / \mathrm{ml}$ & $4.86^{a b}$ & $5.18^{b}$ & $6.94^{a}$ & $7.35^{\mathrm{a}}$ & 0.53 & 0.02 & 0.11 & 0.03 \\
\hline
\end{tabular}

${ }^{1}$ treatments: T1 - no EFS + 20\% RUP, T2 - no EFS + 40\% RUP, T3 - 10\% EFS + 20\% RUP, T4 - 10\% EFS + 40\% RUP; SEM - standard error of the mean, $\mathrm{CIDR}$ - controlled internal drug release; ${ }^{\mathrm{a}-\mathrm{c}}$ - means within the same row with different superscripts are significantly different at $P<0.05$

removal, particularly when combined with higher RUP (63.34 vs $74.40 \mathrm{mg} / \mathrm{dl})$ (Table $4, P<0.05$ ). Blood urea-N levels $24 \mathrm{~h}$ after CIDR removal (12.36 vs $14.60 \mathrm{mg} / \mathrm{dl})$ and 9 days after mating ( $15.21 \mathrm{vs} 17.95 \mathrm{mg} / \mathrm{dl})$ were significantly decreased in response to using $10 \%$ EFS and $40 \%$ RUP in the diets of the ewes (Table 4, $P<0.05$ ).

Supplementing ewes flushing diets with $10 \%$ EFS $+40 \%$ RUP had a significant effect on blood estrogen levels before CIDR removal (21.61 vs $27.83 \mathrm{pg} / \mathrm{ml}$ ) and $24 \mathrm{~h}$ after CIDR removal (32.90 vs $55.76 \mathrm{pg} / \mathrm{ml})($ Table $5, P<0.01)$. The combination of $10 \%$ EFS and $40 \%$ RUP increased blood progesterone levels 9 days after mating $(7.35 \mathrm{vs} 5.18 \mathrm{ng} / \mathrm{ml})$ (Table $5, P<0.05$ ) but a percentage of RUP in the diet had no direct effect. The insulin levels were not consistently affected by the treatment diets.

\section{Reproductive parameters and ovary function}

Fecundity rate (150 vs $108.3 \%)$ was significantly affected by the supplementation of the flushing diets with $10 \%$ EFS $+40 \%$ RUP (Table $6, P<0.05$ ), besides the ewes fed diets containing EFS had higher fecundity rates in comparison to those fed non-EFS diets. In the present study, the twinning rate was not significantly affected, but there were higher rates with the supplementation of $10 \%$ EFS $+40 \%$ RUP in comparison to the group with no EFS in the diet + $20 \%$ RUP (50 vs $10 \%$ ). There was no significant effect of the experimental diet on big follicle numbers or diameter $24 \mathrm{~h}$ before CIDR removal; however, feeding ewes diets including $10 \%$ EFS did produce larger follicles $(8.23$ and $8.59 \mathrm{~mm}) 24 \mathrm{~h}$ after CIDR withdrawal in comparison to the ewes fed non-EFS diets (7.12 and $7.49 \mathrm{~mm}$ ) (Table 7, 
Table 6. Effects of extruded flaxseed (EFS) and rumen undegradable protein (RUP) levels in the flushing diets on the reproductive parameters of the ewes, $\%$

\begin{tabular}{|c|c|c|c|c|c|}
\hline \multirow{2}{*}{ Indices } & \multicolumn{4}{|c|}{ Dietary treatment ${ }^{1}$} & \multirow{2}{*}{$P$-value } \\
\hline & $\mathrm{T} 1$ & $\mathrm{~T} 2$ & T3 & T4 & \\
\hline Fecundity rate & $100^{b}(11 / 11)$ & $108.3^{b}(13 / 12)$ & $133.3^{\mathrm{a}}(16 / 12)$ & $150^{\mathrm{a}}(18 / 12)$ & 0.024 \\
\hline Fertility rate & $90.9(10 / 11)$ & $83.3(10 / 12)$ & $91.67(11 / 12)$ & $100(12 / 12)$ & 0.855 \\
\hline Twinning rate & $10 \quad(1 / 10)$ & $30 \quad(3 / 10)$ & $45.5 \quad(5 / 11)$ & $50 \quad(6 / 12)$ & 0.433 \\
\hline Female lamb rate & $45.5(5 / 11)$ & $38.5 \quad(5 / 13)$ & $31.3 \quad(5 / 16)$ & $66.7(12 / 18)$ & 0.245 \\
\hline Male lamb rate & $54.5(6 / 11)$ & $61.5 \quad(8 / 13)$ & $68.7 \quad(11 / 16)$ & $33.3(6 / 18)$ & 0.245 \\
\hline
\end{tabular}

${ }^{1}$ treatments: T1 - no EFS + 20\% RUP, T2 - no EFS + 40\% RUP, T3 - 10\% EFS + 20\% RUP, T4 - 10\% EFS + 40\% RUP; a-c - means within the same row with different superscripts are significantly different at $P<0.05$

Table 7. Effects of extruded flaxseed (EFS) and rumen undegradable protein (RUP) levels in the flushing diets on the average number and diameter of follicles and corpus luteum of the ewes, $\mathrm{mm}$

\begin{tabular}{|c|c|c|c|c|c|c|c|c|}
\hline \multirow{2}{*}{ Indices } & \multicolumn{4}{|c|}{ Dietary treatment ${ }^{1}$} & \multirow{2}{*}{ SEM } & \multicolumn{3}{|c|}{$P$-value } \\
\hline & $\overline{\mathrm{T} 1}$ & $\mathrm{~T} 2$ & T3 & T4 & & EFS & RUP & EFS^RUP \\
\hline \multicolumn{9}{|l|}{$24 \mathrm{~h}$ before CIDR removal } \\
\hline follicle number & 1.37 & 1.51 & 1.67 & 1.80 & 0.23 & 0.28 & 0.16 & 0.45 \\
\hline follicle diameter & 6.93 & 7.03 & 7.40 & 7.61 & 0.65 & 0.88 & 0.22 & 0.59 \\
\hline \multicolumn{9}{|l|}{$24 \mathrm{~h}$ after CIDR removal } \\
\hline follicle number & 1.42 & 1.58 & 1.75 & 1.89 & 0.29 & 0.31 & 0.95 & 0.16 \\
\hline follicle diameter & $7.12^{\mathrm{c}}$ & $7.49^{\mathrm{bc}}$ & $8.23^{\mathrm{ab}}$ & $8.59^{a}$ & 0.47 & 0.04 & 0.06 & 0.03 \\
\hline \multicolumn{9}{|l|}{9 days after mating } \\
\hline corpus luteum diameter & $7.54^{\mathrm{b}}$ & $7.67^{\mathrm{b}}$ & $9.02^{\mathrm{a}}$ & $9.63^{\mathrm{a}}$ & 0.61 & 0.03 & 0.08 & 0.02 \\
\hline
\end{tabular}

${ }^{1}$ treatments: T1 - no EFS + 20\% RUP, T2 - no EFS + 40\% RUP, T3 - 10\% EFS + 20\% RUP, T4 - 10\% EFS + 40\% RUP; SEM - standard error of the mean, CIDR - controlled internal drug release; ${ }^{a-c}-$ means within the same row with different superscripts are significantly different at $P<0.05$

$P<0.05)$. Feeding EFS and 20 and $40 \%$ RUP diet led to a greater corpus luteum diameter 9 days after mating, comparing to the other dietary treatments.

\section{Discussion}

In the present study, feeding ewes diets including EFS, as a source of unsaturated FA, had no adverse effects on DMI and BW. This is consistent with some previous studies (Benchaar et al., 2012; Suksombat et al., 2014) but Johnson et al. (2002) reported higher DMI and Fiorentini et al. (2015) reported lower DMI in response to feeding oilseeds. According to Soliva et al. (2004), adverse effects of feeding unsaturated FA on ruminal digestion, and in turn DMI, might be attributed to different factors, such as fibre coating and toxic effects on rumen microorganisms. It seems that the greater intakes of ME, CP, NDF, EE and RUP in ewes fed diets with $10 \%$ EFS, is due to higher but insignificant DMI in these groups. Also, another reason could be the higher and significant digestibility of nutrients such as DM, organic matter $(\mathrm{OM})$, acid detergent fibre (ADF), $\mathrm{NDF}$ and $\mathrm{CP}$ in diets containing $10 \%$ EFS when compared to the other diets in the current study (data not shown). These results were consistent with the finding of Neveu et al. (2014) who reported the greater intakes of DM, CP and NDF for cows fed diets with EFS than for cows fed diets without EFS.

We found that $24 \mathrm{~h}$ after CIDR removal (oestrous time), serum glucose concentrations increased in response to the levels of EFS and RUP. Glucose plays a vital role in reproductive performance via the hypothalamus-pituitary-gonad axis (Hess et al., 2005). The use of vegetable oils with high amounts of long-chain unsaturated FA seems to stimulate gluconeogenesis through increasing ruminal propionate production (Jacob et al., 2012; Pi et al., 2019). Furthermore, diets with higher RUP levels could have positive effects on serum glucose through enhancing intestinal availability and uptake. Richards et al. (2003) stated that post-ruminal injection of casein resulted in a faster starch breakdown in the small intestine of steers. We found that diets containing $10 \%$ EFS increased the serum cholesterol level of the ewes $24 \mathrm{~h}$ before CIDR withdrawal. Childs et al. (2008) and Petit et al. (2002) also reported a rise in blood concentration of cholesterol in cows fed different kinds of oilseeds. In our study, the blood urea nitrogen at oestrous and 9 days after mating decreased in the ewes fed the diets containing EFS or 
high levels of RUP. Petit et al. (2002) implied that oilseeds such as flaxseed and rapeseed are effective in controlling the rumen protozoa population, in addition to increasing the protein consumption efficiency. Yoshimura et al. (2018) demonstrated a $24 \%$ decrease in Entodinium population (the most common protozoa species in the rumen) and a significant increase in the concentration of bacterium Butyrivibrio fibrisolvens (the bacterium responsible for rumen biohydrogenation and fibre digestion) by using $25 \mathrm{~g} / \mathrm{kg}$ DM flaxseed oil in the diet of dairy cows.

We detected a significant increase in serum estrogen $24 \mathrm{~h}$ after removing CIDR. In this research, the ewes fed EFS diets had the highest estrogen levels (average $56.03 \mathrm{pg} / \mathrm{ml}$ ). The results of our study are consistent with those of MirzaeiAlamouti et al. (2018), who reported increased blood estrogen concentration in response to dietary PUFA supplementation. In a study, Robinson (1990) stated that higher blood estrogen level is usually associated with larger follicles.

Feeding dairy cattle with $\alpha$-linolenic acid supplements can also increase estrogen concentrations during the follicular phase (Robinson et al., 2002). It seems that a high level of plasma cholesterol during steroidogenesis may accompany a higher concentration of blood estrogen. Additionally, differences in serum estrogen concentrations between EFS diets and non-EFS diets might also be due to the stimulating effect of n-3 PUFA on steroid production. Blood progesterone concentrations 9 days after natural mating (luteal phase) in ewes fed EFS diets were higher than in ewes fed the other diets. Castro et al. (2019) reported elevated serum progesterone concentrations in dairy cows fed long-chain unsaturated FA but Hashem and El-Zarkouny (2014) reported that blood progesterone concentrations in ewes were not influenced by dietary rumen-protected fat. According to Childs et al. (2008), the rise in blood progesterone concentration might be due to an increment in the availability of total plasma cholesterol, the main steroid biosynthesis precursor in the corpus luteum and follicles. The increased progesterone secretion with fat supplementation might also be attributed to larger ovulatory follicle size and in turn to a larger corpus luteum (Staples and Thatcher, 2005).

In the present study, the number of follicles was numerically higher for the ewes fed EFS diets than those fed non-EFS diets. Zeron et al. (2002) reported that unsaturated FA affected the fluidity of the cell phospholipid membrane (necessary for optimal cell function), which can increase follicular growth and development through higher sensitivity (response) of follicular cells to follicle-stimulating hormone (FSH) and luteinizing hormone (LH). An increase in membrane fluidity improves membrane exchange, so it can improve follicular growth and development (Zeron et al., 2002; Zachut et al., 2010), which may partially explain the higher number of follicles on the ewes ovary. Additionally, higher levels of serum cholesterol concentration in the ewes fed EFS diets might be another contributing factor for increasing the growth of the follicles. Feeding EFS diets with high levels of RUP to the ewes resulted in a larger follicle diameter $24 \mathrm{~h}$ after CIDR removal. Similar results were reported by Mirzaei-Alamouti et al. (2018) and Ambrose et al. (2006). The increase in follicle diameter might be attributed to the higher level of plasma estradiol in the experimental ewes since both LH secretion from the anterior pituitary gland and the number of LH receptor granulosa cells increase in response to blood estradiol, which in turn can also boost the growth of the dominant follicle (Rosenfeld et al., 2001).

The percentage of fecundity rate was greater for the ewes fed EFS diets but there was not any significant difference in other reproductive traits such as fertility and twinning rate. However, Ambrose et al. (2006) showed that n-3 PUFA contribute to the embryo survival and corpus luteum maintenance after breeding, due to attenuated prostaglandin F2 $\alpha$ (PGF2 $\alpha$ ) synthesis. Moreover, Thatcher and Staples (2007) reported that feeding the oilseed sources rich in n-3 PUFA also improved reproductive performance due to their effects on increasing the growth rate and the number of mature follicles and corpus luteum. Besides, the level of dietary protein has a positive effect on FSH pulses and estrogen synthesis (Scaramuzzi et al., 2006; Castro et al., 2019) as well as subsequent offspring number (Daghigh Kia et al., 2012). Similarly, Hoon et al. (2000) reported that diets containing protein supplement at $400 \mathrm{~g} /$ day enhanced fertility rates, suggesting that greater absorption of protein can elevate FSH pulses and fertility rates.

\section{Conclusions}

The addition of $10 \%$ extruded flaxseed (EFS, as a source of polyunsaturated fatty acids) plus $40 \%$ rumen undegradable protein (RUP) to the diets of the ewes at the flushing stage increased the blood levels of estrogen and progesterone with a corresponding improvement in fecundity rates. Furthermore, it was shown that diets containing $10 \%$ EFS 
plus 40\% RUP promoted follicle and corpus luteum diameters. While there are several possible mechanisms proposed in the literature for the influence of the fatty acids from EFS plus RUP on ovary physiology and function, none are conclusive, so more research is needed in this regard.

\section{Acknowledgements}

We are thankful to Vice Chancellor for Research and Technology of Bahonar University of Kerman (Iran) for financial support (Grant number: G-311/8759). The authors acknowledge the support of the crew in the sheep unit and laboratory throughout the research. We also appreciate Professor Richard Williams's help for his critical input in editing the final iteration of the manuscript.

\section{Conflict of interest}

The authors declare that there is no conflict of interest.

\section{References}

Aboozar M., Amanlou H., Aghazadeh A.M., Adl K.N., Moeini M., Tanha T., 2012. Impacts of different levels of RUP on performance and reproduction of Holstein fresh cows. J. Anim. Vet. Adv. 11, 1338-1345, https://doi.org/10.3923/ javaa.2012.1338.1345

Ambrose D.J., Kastelic J.P., Corbett R., Pitney P.A., Petit H.V., Small A.J., Zalkovic P., 2006. Lower pregnancy losses in lactating dairy cows fed a diet enriched in a-linolenic acid. J. Dairy Sci. 89, 3066-3074, https://doi.org/10.3168/jds. S0022-0302(06)72581-4

Benchaar C., Romero-Pérez G.A., Chouinard P.Y., Hassanat F., Eugene M., Petit H.V., Côrtes C., 2012. Supplementation of increasing amounts of linseed oil to dairy cows fed total mixed rations: Effects on digestion, ruminal fermentation characteristics, protozoal populations, and milk fatty acid composition. J. Dairy Sci. 95, 4578-4590, https://doi. org/10.3168/jds.2012-5455

Berardinelli J.G., Weng J., Burfening P.J., Adair R., 2001. Effect of excess degradable intake protein on early embryonic development, ovarian steroids, and blood urea nitrogen on days $2,3,4$, and 5 of the estrous cycle in mature ewes. $J$. Anim. Sci. 79, 193-199, https://doi.org/10.2527/2001.791193x

Castro T., Martinez D., Isabel B., Cabezas A., Jimeno V., 2019. Vegetable oils rich in polyunsaturated fatty acids supplementation of dairy cows' diets: effects on productive and reproductive performance. Animals 9, 205, https://doi.org/10.3390/ ani9050205

Cerri R.L.A., Juchem S.O., Chebel R.C., Rutigliano H., Bruno R.G.S., Galvão K.N., Thatcher W.W., Santos J.E.P., 2009. Effect of fat source differing in fatty acid profile on metabolic parameters, fertilization, and embryo quality in high-producing dairy cows. J. Dairy Sci. 92, 1520-1531, https://doi.org/10.3168/jds.20081614
Childs S., Lynch C.O., Hennessy A.A., Stanton C., Wathes D.C., Sreenan J.M., Diskin M.G., Kenny D.A., 2008. Effect of dietary enrichment with either n-3 or n-6 fatty acids on systemic metabolite and hormone concentration and ovarian function in heifers. Animal 2, 883-893, https://doi.org/10.1017/ S1751731108002115

Daghigh Kia H., Mohamadi Chapdareh W., Hossein Khani A., Moghaddam G., Rashidi A., Sadri H., Alijani S., 2012. Effects of flushing and hormonal treatment on reproductive performance of Iranian Markhoz goats. J. Anim. Physiol. Anim. Nutr. 96, 1157-1164, https://doi.org/10.1111/j.14390396.2011.01234.X

Fiorentini G., Carvalho I.P.C., Messana J.D., Canesin R.C., Pablo S., Castagnino P.S., Lage J.F., Arcuri P.B., Berchielli T.T., 2015. Effect of lipid sources with different fatty acid profiles on intake, nutrient digestion and ruminal fermentation of feedlot Nellore steers. Asian-Australas. J. Anim. Sci. 28, 1583-1591, https://doi.org/10.5713/ajas.15.0130

Hashem N.M., El-Zarkouny S.Z., 2014. Effect of short-term supplementation with rumen-protected fat during the late luteal phase on reproduction and metabolism of ewes. J. Anim. Physiol. Anim. Nutr. 98, 65-71, https://doi.org/10.1111/ jpn.12032

Hess B.W., Lake S.L., Scholljegerses E.J., Weston T.R., Nayigihugu V., Molle J.D.C., Moss G.E., 2005. Nutritional controls of beef cow reproduction. J. Anim. Sci. 83, Suppl. E, E90-E106, https://doi.org/10.2527/2005.8313_supplE90x

Hoon J.H., Herselman M.J., Van Heerden M., Pretorius A.P., 2000. The effect of bypass protein supplementation on the reproductive performance of Merino sheep grazing mixed karoo veld. S. Afr. J. Anim. Sci. 30, Suppl. 1, 60-61, https://doi.org/10.4314/ sajas.v30i4.3909

Jacob A.B., Balakrishnan V., Kathirvelan C., 2012. Effect of amount and source of vegetable oils in a high fibrous cattle diet on in vitro rumen fermentation, nutrient degradability and rumen cis-9, trans-11 CLA concentration. J. Appl. Anim. Res. 40, 148-153, https://doi.org/10.1080/09712119.2011.644169

Johnson K.A., Kincaid R.L., Westberg H.H., Gaskins C.T., Lamb B.K., Cronrath J.D., 2002. The effect of oilseeds in diets of lactating cows on milk production and methane emissions. J. Dairy Sci. $\quad 85, \quad 1509-1515$, https://doi.org/10.3168/jds.S00220302(02) $74220-3$

Marei W.F., Wathes D.C., Fouladi-Nashta A.A., 2009. The effect of linolenic acid on bovine oocyte maturation and development. Biol. Reprod. 81, 1064-1072, https://doi.org/10.1095/ biolreprod.109.076851

McCormick M.E., French D.D., Brown T.F., Cuomo G.J., Chapa A.M., Fernandez J.M., Beatty J.F., Blouin D.C., 1999. Crude protein and rumen undegradable protein effects on reproduction and lactation performance of Holstein cows. J. Dairy Sci. 82, 26972708, https://doi.org/10.3168/jds.S0022-0302(99)75526-8

Mikolayunas C., Thomas D.L., Armentano L.E., Berger Y.M., 2011. Effect of rumen-undegradable protein supplementation and fresh forage composition on nitrogen utilization of dairy ewes. J. Dairy Sci. 94, 416-425, https://doi.org/10.3168/jds.20103656

Mirzaei-Alamouti H., Mohammadi Z., Shahir M.H., Vazirigohar M., Mansouryar M., 2018. Effects of short-term feeding of different sources of fatty acids in pre-mating diets on reproductive performance and blood metabolites of fat-tailed Iranian Afshari ewes. Theriogenology 113, 85-91, https://doi. org/10.1016/j.theriogenology.2018.02.007

Neveu C., Baurhoo B., Mustafa A., 2014. Effect of feeding extruded flaxseed with different grains on the performance of dairy cows and milk fatty acid profile. J. Dairy Sci. 97, 1543-1551, https://doi.org/10.3168/jds.2013-6728 
NRC (National Research Council), 2007. Nutrient Requirements of Small Ruminants: Sheep, Goats, Cervids, and New World Camelids. The National Academies Press. Washington, DC (USA), https://doi.org/10.17226/11654

Petit H.V., Dewhurst R.J., Scollan N.D., Proulx J.G., Khalid M., Haresign W., Twagiramungu H., Mann G.E., 2002. Milk production and composition, ovarian function, and prostaglandin secretion of dairy cows fed omega-3 fats. J. Dairy Sci. 85, 889-899, https://doi.org/10.3168/jds.S0022-0302(02)74147-7

Pi Y., Ma L., Pierce K.M., Wang H.R., Xu J.C., Bu D.P., 2019. Rubber seed oil and flaxseed oil supplementation alter digestion, ruminal fermentation and rumen fatty acid profile of dairy cows. Animal 13, 2811-2820, https://doi.org/10.1017/ S175173111900137X

Richards C.J., Swanson K.C., Paton S.J., Harmon D.L., Huntington G.B., 2003. Pancreatic exocrine secretion in steers infused postruminally with casein and cornstarch. J. Anim. Sci. 81,1051-1056, https://doi.org/10.2527/2003.8141051x

Robinson J.J., 1990. Nutrition in the reproduction of farm animals. Nutr. Res. Rev. 3, 253-276, https://doi.org/10.1079/NRR19900015

Robinson R.S., Pushpakumara P.G.A., Cheng Z., Peters A.R., Abayasekara D.R.E., Wathes D.C., 2002. Effects of dietary polyunsaturated fatty acids on ovarian and uterine function in lactating dairy cows. Reproduction 124, 119-131, https://doi. org/10.1530/rep.0.1240119

Rosenfeld C.S., Wagner J.S., Roberts R.M., Lubahn D.B., 2001. Intraovarian actions of estrogen. Reproduction 122, 215-226, https://doi.org/10.1530/rep.0.1220215

Scaramuzzi R.J., Campbell B.K., Downing J.A., Kendall N.R., Khalid M., Muñoz-Gutiérrez M., Somchit A., 2006. A review of the effects of supplementary nutrition in the ewe on the concentrations of reproductive and metabolic hormones and the mechanisms that regulate folliculogenesis and ovulation rate. Reprod. Nutr. Dev. 46, 339-354, https://doi.org/10.1051/ rnd:2006016

Soliva C.R., Meile L., Cieślak A., Kreuzer M., Machmüller A., 2004. Rumen simulation technique study on the interactions of dietary lauric and myristic acid supplementation in suppressing ruminal methanogenesis. Br. J. Nutr. 92, 689-700, https://doi.org/10.1079/bjn20041250
Staples C.R., Thatcher W.W., 2005. Effects of fatty acids on reproduction of dairy cows. In: P.C. Garnsworthy, J. Wiseman (Editors). Recent Advances in Animal Nutrition. Nottingham University Press. Nottingham (UK), pp. 229-256, https://doi. org/10.5661/recadv-05-229

Suksombat W., Thanh L.P., Meeprom C., Mirattanaphrai R., 2014. Effects of linseed oil or whole linseed supplementation on performance and milk fatty acid composition of lactating dairy cows. Asian-Australas. J. Anim. Sci. 27, 951-959, https://doi. org/10.5713/ajas.2013.13665

Thatcher W.W., Staples R.C., 2007. Using fats and fatty acids to enhance reproductive performance. In: Proceedings of the $5^{\text {th }}$ Mid-Atlantic Nutrition Conference. University of Maryland. College Park, MD (USA), pp. 116-129

Wonnacott K.E., Kwong W.Y., Hughes J., Salter A.M., Lea R.G., Garnsworthy P.C., Sinclair K.D., 2010. Dietary omega-3 and-6 polyunsaturated fatty acids affect the composition and development of sheep granulosa cells, oocytes and embryos. Reproduction 139, 57-69, https://doi.org/10.1530/REP-090219

Yoshimura E.H., Santos N.W., Machado E., Agustinho B.C., Pereira L.M., de Aguiar S.C., Franzolin R., Gasparino E., dos Santos G.T., Zeoula L.M., 2018. Effects of dairy cow diets supplied with flaxseed oil and propolis extract, with or without vitamin $\mathrm{E}$, on the ruminal microbiota, biohydrogenation, and digestion. J. Anim. Feed Sci. Technol. 241, 163-172, https:// doi.org/10.1016/j.anifeedsci.2018.04.024

Zachut M., Dekel I., Lehrer H., Arieli A., Arav A., Livshitz L., Yakoby S., Moallem U., 2010. Effects of dietary fats differing in $n-6: n-3$ ratio fed to high-yielding dairy cows on fatty acid composition of ovarian compartments, follicular status, and oocyte quality. J. Dairy Sci. 93, 529-545, https://doi.org/10.3168/jds.20092167

Zeron Y., Sklan D., Arav A., 2002. Effect of polyunsaturated fatty acid supplementation on biophysical parameters and chilling sensitivity of ewe oocytes. Mol. Reprod. Dev. 61, 271-278, https://doi.org/10.1002/mrd.1156 